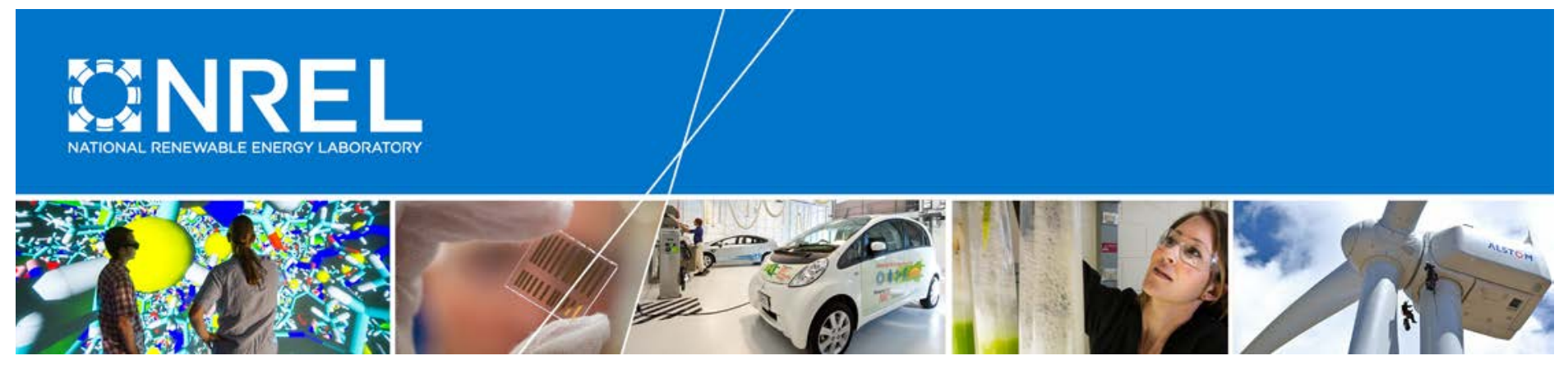

\title{
Economic Analysis Case Studies of Battery Energy Storage with SAM
}

Nicholas DiOrio, Aron Dobos, and Steven Janzou National Renewable Energy Laboratory

NREL is a national laboratory of the U.S. Department of Energy Office of Energy Efficiency \& Renewable Energy Operated by the Alliance for Sustainable Energy, LLC

This report is available at no cost from the National Renewable Energy Laboratory (NREL) at www.nrel.gov/publications.

Technical Report

NREL/TP-6A20-64987

November 2015 


\section{Economic Analysis Case Studies of Battery Energy Storage with SAM}

Nicholas DiOrio, Aron Dobos, and

Steven Janzou

National Renewable Energy Laboratory

Prepared under Task No. SS139001

NREL is a national laboratory of the U.S. Department of Energy Office of Energy Efficiency \& Renewable Energy Operated by the Alliance for Sustainable Energy, LLC

This report is available at no cost from the National Renewable Energy Laboratory (NREL) at www.nrel.gov/publications.

National Renewable Energy Laboratory 15013 Denver West Parkway Golden, CO 80401

303-275-3000 • www.nrel.gov

\section{Technical Report}

NREL/TP-6A20-64987

November 2015

Contract No. DE-AC36-08GO28308 


\title{
NOTICE
}

This report was prepared as an account of work sponsored by an agency of the United States government. Neither the United States government nor any agency thereof, nor any of their employees, makes any warranty, express or implied, or assumes any legal liability or responsibility for the accuracy, completeness, or usefulness of any information, apparatus, product, or process disclosed, or represents that its use would not infringe privately owned rights. Reference herein to any specific commercial product, process, or service by trade name, trademark, manufacturer, or otherwise does not necessarily constitute or imply its endorsement, recommendation, or favoring by the United States government or any agency thereof. The views and opinions of authors expressed herein do not necessarily state or reflect those of the United States government or any agency thereof.

This report is available at no cost from the National Renewable Energy Laboratory (NREL) at www.nrel.gov/publications.

Available electronically at SciTech Connect http:/www.osti.gov/scitech

Available for a processing fee to U.S. Department of Energy and its contractors, in paper, from:

\author{
U.S. Department of Energy \\ Office of Scientific and Technical Information \\ P.O. Box 62 \\ Oak Ridge, TN 37831-0062 \\ OSTI http://www.osti.gov \\ Phone: 865.576.8401 \\ Fax: 865.576.5728 \\ Email: reports@osti.gov
}

Available for sale to the public, in paper, from:

\author{
U.S. Department of Commerce \\ National Technical Information Service \\ 5301 Shawnee Road \\ Alexandria, VA 22312 \\ NTIS http://www.ntis.gov \\ Phone: 800.553 .6847 or 703.605 .6000 \\ Fax: 703.605.6900 \\ Email: orders@ntis.gov
}




\section{Executive Summary}

Behind-the-meter electric-energy storage has been considered recently as a possible means of enabling higher amounts of renewable energy on the grid. States such as California have introduced mandates and subsidies to spur adoption. This work considers customer sited behindthe-meter storage coupled with photovoltaics (PV) and presents case studies of the financial benefit of customer-installed systems in California and Tennessee. Different dispatch strategies, including manual scheduling and automated peak-shaving were explored to determine ideal ways to use the storage system to increase the system value and mitigate demand charges. Incentives, complex electric tariffs, and site-specific load and PV data were used to perform detailed analysis using the free, publicly available System Advisor Model (SAM) tool. We find that installation of photovoltaics with a lithium-ion battery system in Los Angeles and installation of lithium-ion batteries without photovoltaics in Knoxville yields positive net-present values considering high demand charge utility rate structures, battery costs of $\$ 300 / \mathrm{kWh}$, and dispatching the batteries using perfect day-ahead forecasting. All other scenarios considered cost the customer more than the savings accrued. General conclusions about influential factors in determining net present value remain elusive because our analysis shows high sensitivity of battery economics to the complex interplay among scenario parameters and location-specific information. 


\section{Table of Contents}

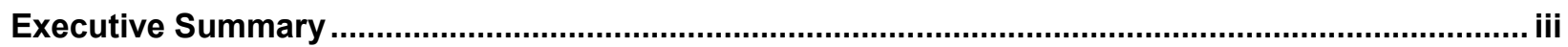

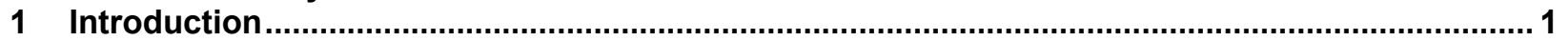

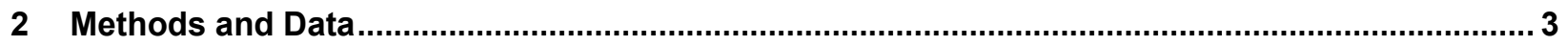

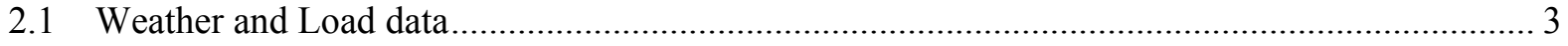

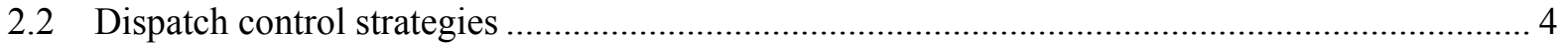

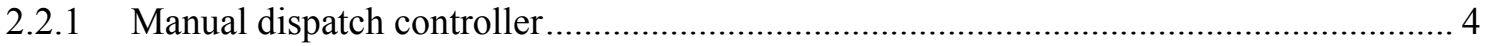

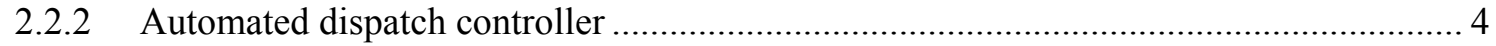

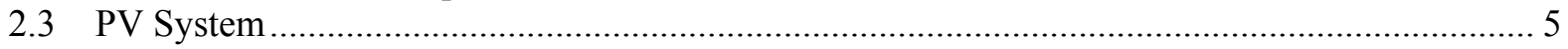

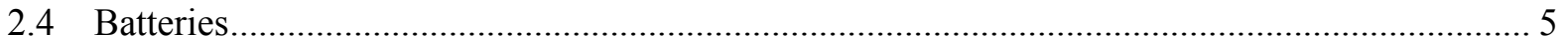

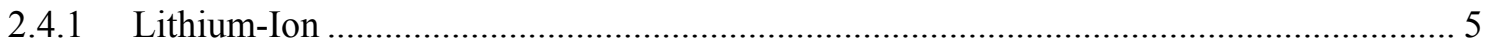

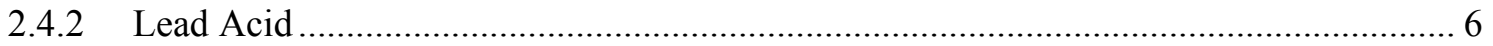

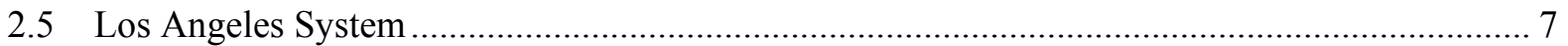

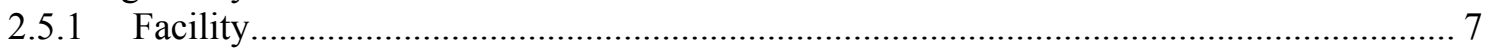

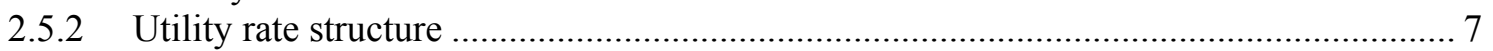

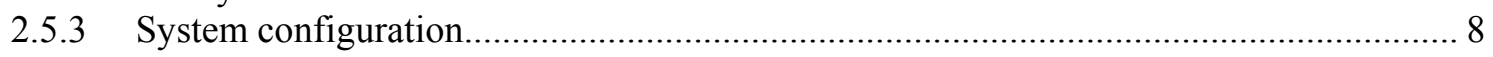

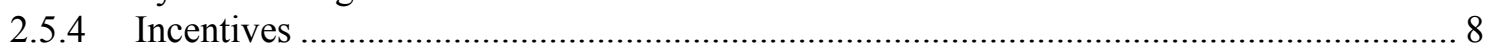

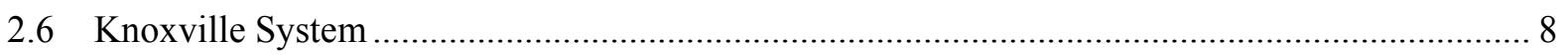

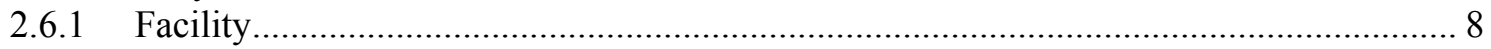

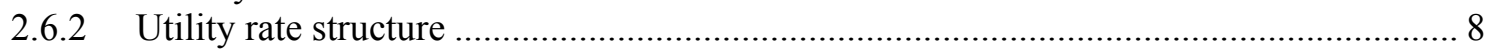

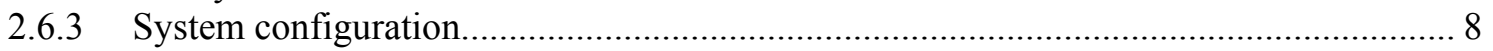

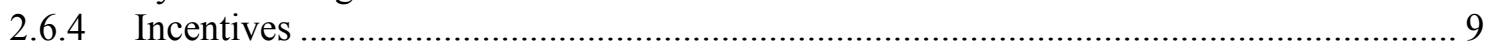

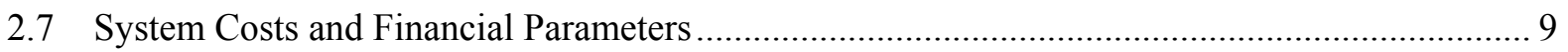

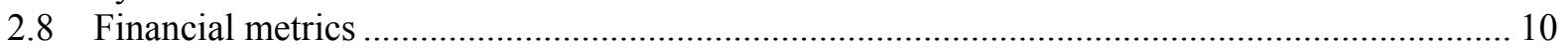

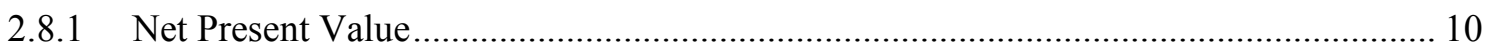

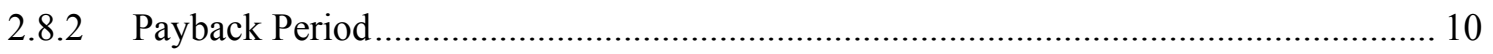

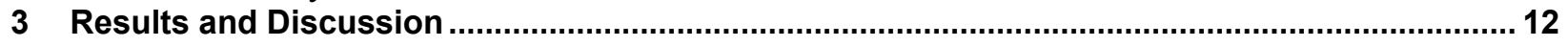

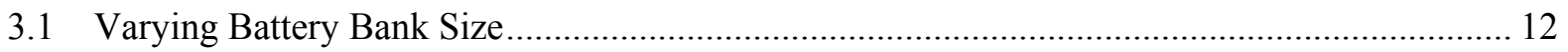

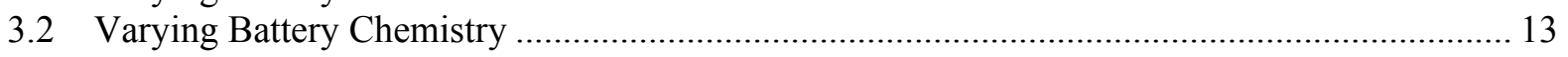

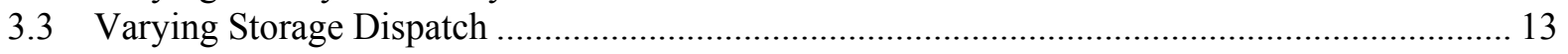

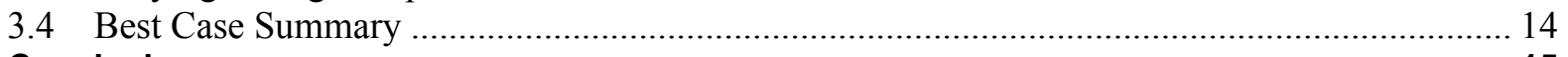

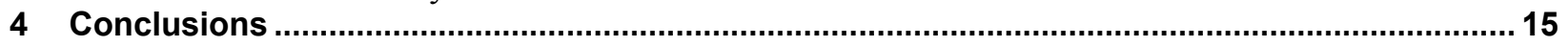




\section{Introduction}

Mandates for energy storage coupled with incentives and the high-profile introduction of batteries for behind-the-meter storage applications have led to an increased need for tools and analysis that evaluates financial benefit under various scenarios. In 2010 the California Public Utilities Commission released a target of 1.3 gigawatts $(\mathrm{GW})$ of energy storage in the state by 2020 [1]. The $1.3 \mathrm{GW}$ target is broken up between the public utilities Pacific Gas \& Electric (PG\&E), Southern California Edison (SCE) and San Diego Gas \& Electric (SDG\&E). Each has specific procurement targets for transmission, distribution and customer-sited storage. Statewide, the customer-sited storage target totals 200 megawatts (MW). California has also instituted an incentive program for energy storage projects through its Self-Generation Incentive Program (SGIP) [2]. 2014 incentive rates for advanced energy storage projects were $\$ 1.62 / \mathrm{W}$ for systems with up to $1 \mathrm{MW}$ capacity, with declining rates up to $3 \mathrm{MW}$. ConEdison in New York State also provides an incentive of $\$ 2.10 / \mathrm{W}$ for battery energy storage projects completed prior to June 1 , 2016 [3]. Elsewhere, other states such as Hawaii have energy storage demonstration projects in progress [4].

Incentives offer additional financial benefit to energy storage systems, but the systems must serve an ongoing role in providing value to customers to justify the capital expenditure. For behind-the-meter applications, the reduction of demand charges is one way that these systems reduce commercial customer bills. A previous study [5] used the Battery Lifetime Analysis and Simulation Tool (BLAST) developed at the National Renewable Energy Laboratory (NREL) to consider optimizing the size and operation of an energy storage system providing demand charge management. Battery degradation and capital replacement costs were not considered. This study will similarly conduct demand charge management analysis, but will focus on two specific scenarios using NREL's freely-available System Advisor Model (SAM) tool. SAM links a high temporal resolution PV-coupled battery energy storage performance model to detailed financial models to predict the economic benefit of a system. The battery energy storage models provide the ability to model lithium-ion or lead-acid systems over the lifetime of a system to capture the variable nature of battery replacements.

Additional value streams such as using storage to provide ancillary services within California Independent System Operator's (CAISO) or other markets are not considered here. For the rate structures considered, it is assumed that net energy metering (NEM) with a monthly rollover of excess energy is included. Some additional rules with NEM exist, particularly within Southern California Edison [6]. The battery storage systems considered in this analysis attempt to remain compliant with power output restrictions by restricting the battery nominal capacity to remain lower than the photovoltaic nominal capacity. This restriction was enforced for all rate structures considered to isolate the contribution batteries can make to minimizing demand charges.

Only commercial facilities were considered since residential utility rate structures typically do not include demand charges. Commercial facilities in Los Angeles, CA and Knoxville, TN were considered. For PV installations sized to serve $20 \%$ and $50 \%$ of the peak load, lithium-ion and lead-acid battery banks of varying sizes were compared to evaluate net-present value and payback period for the system by considering variable replacement times, utility rate structures, and storage dispatch strategies. The analysis reveals the flexibility of SAM in evaluating 
$\mathrm{PV}+$ Storage systems for behind-the-meter applications and highlights how systems can be evaluated to determine financially viable configurations. 


\section{Methods and Data}

SAM is a free software tool which can perform detailed performance and financial analysis across a variety of renewable energy technologies, including PV+Storage for behind-the-meter analysis. Details on the PV modeling capabilities can be found in [7], while details on the battery modeling can be found in [8]. The study uses SAM to process subhourly weather and load data, predict PV generation, and automatically dispatch the battery to reduce peak demand charges. The simulations are conducted over a 25 year analysis period to capture full lifetime costs including battery bank replacements. Two facilities are studied, one in Los Angeles and one in Knoxville. For each study, local utility rate structures are implemented and parametric analysis is completed to evaluate the effect of PV and battery bank sizing on the system net present value. Additionally, different battery control strategies are explored to evaluate the importance of dispatch control on overall economics.

\subsection{Weather and Load data}

One-minute weather data was obtained from NREL's Measurement and Instrumentation Data Center (MIDC). The weather data was taken from 2012 at the weather stations nearest to the commercial facilities studied.

Electric load data for 2012 was taken from EnerNOC's free online database for 98 commercial facilities [9]. The datasets provide electricity demand information in 5-minute time-steps over one year. Figure 1 shows one day of load and irradiance data for the Los Angeles commercial facility. The plot shows that the facility experiences higher load in the early morning and late evening. Figure 2 shows the Knoxville facility electric load and beam irradiance for the same day. The Knoxville site experiences higher load during the afternoon and early evening hours.
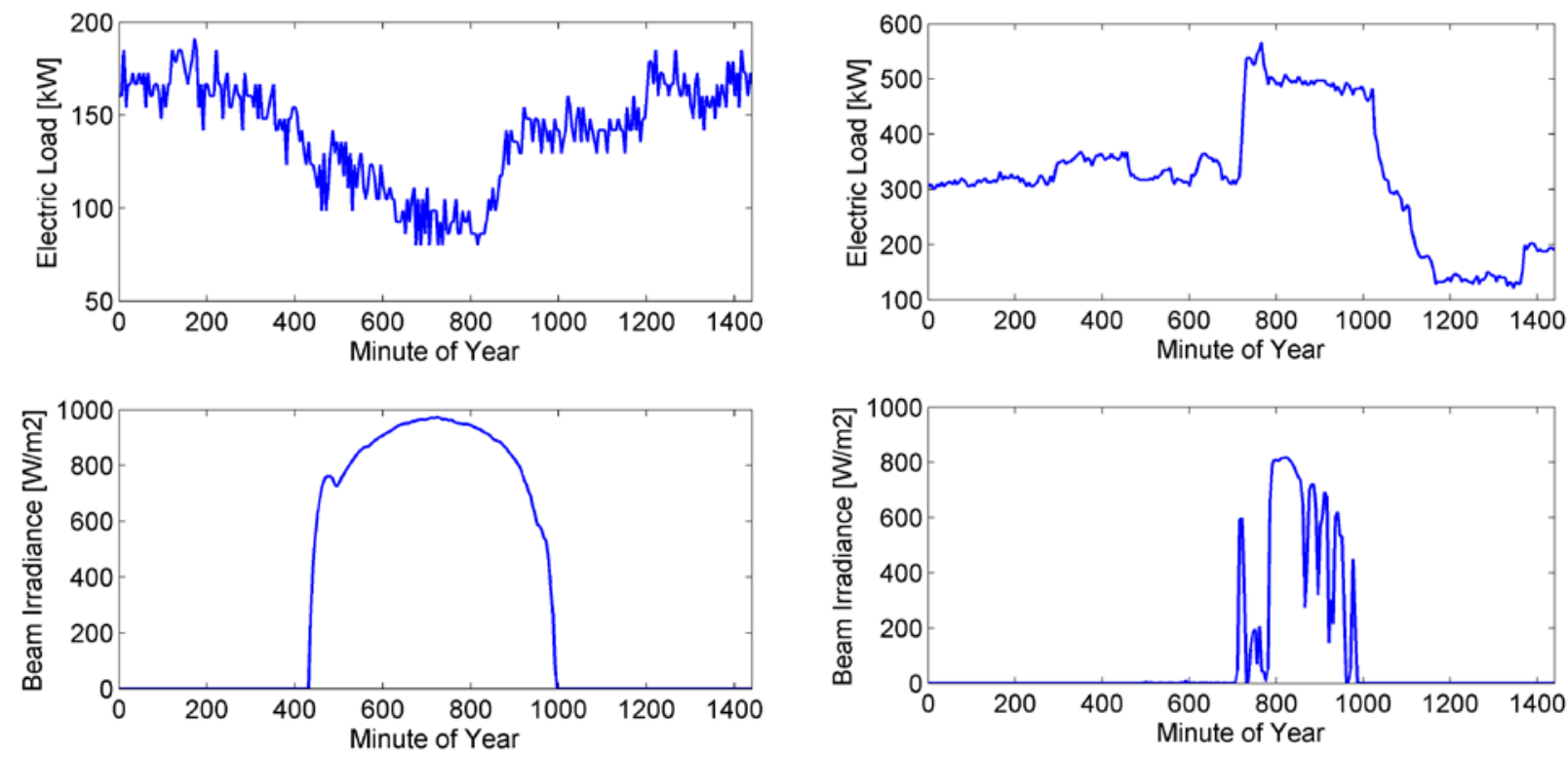

Figure 1: January $1^{\text {st }}$ load and irradiance data for LA facility

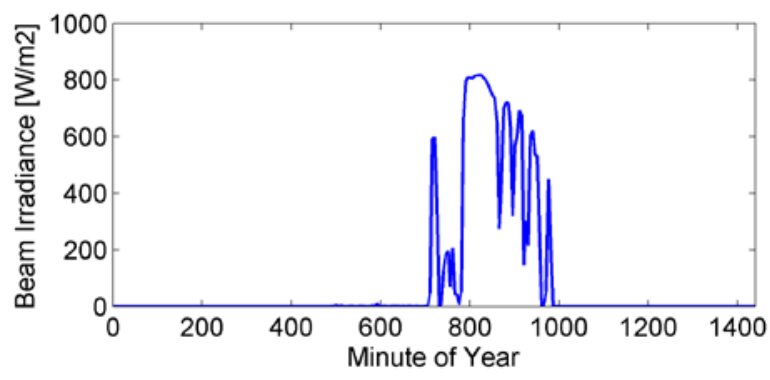

Figure 2: January 1st load and irradiance data for Knoxville facility 


\subsection{Dispatch control strategies}

\subsubsection{Manual dispatch controller}

The manual dispatch controller allows a user to choose how to charge and discharge the battery depending on the hour and month. This controller is described in detail in [8].

\subsubsection{Los Angeles}

To account for the load profile seen in Figure 1, the manual controller was programmed with the schedule outlined in Table 1.

Table 1: LA Manual Dispatch Controller

\begin{tabular}{l|l|l}
\hline Month & Time & Strategy \\
\hline All & $\begin{array}{l}12 \mathrm{am}-6 \mathrm{am} \mathrm{\&} \\
4 \mathrm{pm}-12 \mathrm{am}\end{array}$ & $\begin{array}{l}\text { Charge from PV } \\
\text { Charge from Grid } \\
\text { Discharge up to 0.5\% capacity each time step (5 } \\
\text { minutes) }\end{array}$ \\
\hline All & $7 \mathrm{am}-3 \mathrm{pm}$ & $\begin{array}{l}\text { Charge from PV } \\
\text { Charge From Grid }\end{array}$ \\
\hline
\end{tabular}

\subsubsection{Knoxville}

To account for the load profile seen in Figure 2, the manual controller was programmed with the schedule outlined in Table 2 .

Table 2: Knoxville Manual Dispatch Controller

\begin{tabular}{l|l|l}
\hline Month & Time & Profile \\
\hline All & $12 \mathrm{pm}-7 \mathrm{pm}$ & $\begin{array}{l}\text { Charge from PV } \\
\text { Charge from Grid } \\
\text { Discharge up to 0.5\% capacity each time step (5 } \\
\text { minutes) }\end{array}$ \\
\hline All & $\begin{array}{l}12 \mathrm{am}-11 \mathrm{am} \& \\
8 \mathrm{pm}-12 \mathrm{am}\end{array}$ & $\begin{array}{l}\text { Charge from PV } \\
\text { Charge From Grid }\end{array}$ \\
\hline
\end{tabular}

\subsubsection{Automated dispatch controller}

The automated dispatch controller runs in a look-ahead mode. In look-ahead mode, perfect PV and load forecasting are performed over a period of 24 hours and the dispatch strategy is set to reduce peak grid purchases as much as possible. This mode illustrates an upper bound on controller performance for a 24 hour look ahead.

The automated controller is not yet publicly released within SAM. Given the predicted load and $\mathrm{PV}$ profile, the automated control algorithm proceeds by computing the net grid power required without a battery system for every time step. It sorts the powers to determine the highest grid power required. The battery is then programmed to discharge throughout the day to reduce the peak grid powers as much as possible before reaching the minimum state of charge. 


\subsection{PV System}

SunPower SPR-210-BLK-U modules [10] with SMA America: STP24000TL-US-10 480V inverters [11] were selected as baseline system hardware for both case studies. Two system sizes were considered for each location. One system was sized with the goal of providing approximately $20 \%$ of peak power from PV during full production. The other system was sized to provide about $50 \%$ of peak power.

\subsection{Batteries}

Two types of battery systems were considered, lithium-ion and lead-acid. Lead-acid batteries have been in use for many years and are typically less expensive than lithium-ion batteries, but lithium-ion batteries typically have better lifetime cycling properties, potentially reducing the number of battery replacements over a system lifetime [12].

\subsubsection{Lithium-Ion}

Daily-cycle lithium-ion nickel manganese cobalt oxide (NMC) batteries similar to the Tesla Powerwall batteries were selected for the lithium-ion battery bank. Table 3 shows properties for a single Powerwall battery pack.

Table 3: Tesla Powerwall Specifications [13]

\begin{tabular}{l|l}
\hline Property & Value \\
\hline Price & $\$ 3000$ \\
\hline Capacity & $7 \mathrm{kWh}$ \\
\hline Power & $2.0 \mathrm{~kW}$ continuous, $3.3 \mathrm{~kW}$ peak \\
\hline Efficiency & $92 \%$ \\
\hline Voltage & $350-450 \mathrm{~V}$ \\
\hline Current & $5.8 \mathrm{~A} \mathrm{nominal}, 8.6 \mathrm{~A}$ peak \\
\hline Weight & $100 \mathrm{~kg}$ \\
\hline Dimensions & $1300 \mathrm{~mm} \times 860 \mathrm{~mm} \times 180 \mathrm{~mm}$ \\
\hline
\end{tabular}

This analysis assumed that $7 \mathrm{kWh}$ of energy can be cycled daily within the minimum and maximum state of charge limits, which are assumed to be $30 \%$ and $100 \%$ respectively. This implies a full capacity of $10 \mathrm{kWh}$ which is assumed to cost $\$ 3000$, implying a price of $\$ 300 / \mathrm{kWh}$. We assume this cost includes installation and permitting, but additional analysis would be required to incorporate these costs at a specific site.

This analysis assumed that the battery begins with $7 \mathrm{kWh}$ of daily cycle life and is replaced once the maximum capacity has degraded to $70 \%$ of the original value. As detailed lifetime cycling information is not readily available, we assumed that the batteries can be fully cycled daily for five years beyond the stated 10 -year warranty period before the battery capacity degrades to $70 \%$ of the original installed capacity, at which point the battery bank must be replaced. This implies about 365 cycles per year, for 15 years, or 5475 cycles. 


\subsubsection{Lead Acid}

Deep cycle valve-regulated lead-acid (VRLA) absorbed glass mat (AGM) batteries were selected for the lead acid battery bank similar to the Outback Energy Cell. Table 4 shows the Outback EnergyCell properties.

Table 4: Outback EnergyCell 200RE Specifications [14] [15]

\begin{tabular}{l|l}
\hline Property & Value \\
\hline Price & $\$ 425$ \\
\hline Capacity & $1.680 \mathrm{kWh}$ (4 hour discharge) \\
\hline Power & $420 \mathrm{~W}$ (4 hour discharge) \\
\hline Efficiency & Unlisted \\
\hline Voltage & $12 \mathrm{~V}$ \\
\hline Current & $35 \mathrm{~A} \mathrm{(4} \mathrm{hour} \mathrm{discharge),} \mathrm{30} \mathrm{A} \mathrm{(charging)}$ \\
\hline Weight & $60 \mathrm{~kg}$ \\
\hline Dimensions & $320 \mathrm{~mm} \times 551 \mathrm{~mm} \times 126 \mathrm{~mm}$ \\
\hline
\end{tabular}

The lead-acid system was similarly allowed to cycle from $30 \%$ to $100 \%$ state-of-charge, or approximately $1.18 \mathrm{kWh}$ per battery at a four-hour discharge rate. The cost of one battery was found to be about $\$ 425$, implying a price of $\$ 255 / \mathrm{kWh}$. This cost again assumes that installation and permitting are included, though additional analysis would need to be performed for a specific site. No efficiency was listed for the battery, so single point AC/DC and DC/AC conversion efficiencies of $92 \%$ were assumed. These efficiencies were chosen to remain consistent with the lithium-ion system.

The battery bank is assumed to be replaced when the maximum capacity has degraded to $70 \%$ of the original value. The following cycling information was used from the battery spec sheet [14].

Table 5: Outback EnergyCell 200 RE Lifetime

\begin{tabular}{c|c|c}
\hline Average Depth-of-Discharge (\%) & Cycles Elapsed & Relative Maximum Capacity (\%) \\
\hline 10 & 6200 & 80 \\
\hline 20 & 5700 & 80 \\
\hline 50 & 1800 & 80 \\
\hline 80 & 600 & 80 \\
\hline 100 & 425 & 80 \\
\hline
\end{tabular}

As the battery is allowed to consistently discharge $70 \%$ of its energy, the expected lifetime before degradation to $70 \%$ of maximum capacity and replacement is about 1400 cycles, as shown in Table 5. The "Relative Maximum Capacity" is the maximum capacity of the battery relative to the original maximum capacity, which changes over time as cycles elapse. 


\subsection{Los Angeles System}

Due to favorable climate, incentives for battery storage systems, and its utility rate structures, California provides an ideal location for performing a detailed financial analysis on the merits of installing a battery bank with PV.

\subsubsection{Facility}

EnerNOC facility number 384 was examined for this study of the hypothetical costs and benefits of battery storage. The 27,625 $\mathrm{ft}^{2}$ grocery store/market is located in Los Angeles. The facility had an annual peak load of about $247 \mathrm{~kW}$ in 2012 and no photovoltaic or battery storage system.

\subsubsection{Utility rate structure}

After consideration of several commercial rate structures with demand charges, Southern California Edison's TOU-GS-2 rate structure was selected [16] for analytic purposes. This rate structure serves medium-size commercial and industrial facilities with peak loads between 20 $200 \mathrm{~kW}$. The structure was chosen because after the installation of PV and batteries, the load of the facility under study falls within the rate structure load range. Option B of the rate structure was selected to further study controller behavior with time-of-use demand charges. The rate structure is monthly such that demand charges are reset at the end of each month. The utility rate structure as reproduced from the Utility Rate Database (URDB) [17] is shown in Table 6). We did not gather data on the facility's actual tariff.

Table 6: Southern California Edison TOU-GS-2 Option B Rate Structure

\begin{tabular}{|c|c|c|}
\hline Charge & Time & Cost \\
\hline Fixed charge & All & $267.4(\$)$ \\
\hline Base demand charge & All & $13(\$ / k W)$ \\
\hline \multirow[t]{3}{*}{ TOU demand charge } & $\begin{array}{l}\text { June - September } \\
8 \text { am - } 12 \text { pm, } 6 p m-11 \text { pm. (Monday-Friday) } \\
\text { All day (Saturday-Sunday) }\end{array}$ & $4.88(\$ / k W)$ \\
\hline & $\begin{array}{l}\text { June - September } \\
\text { Noon - 6pm (Monday-Friday) }\end{array}$ & $16.69(\$ / k W)$ \\
\hline & All other times & $0(\$ / k W)$ \\
\hline \multirow[t]{5}{*}{ TOU energy charge } & $\begin{array}{l}\text { January - May, October - December } \\
12 \text { am - } 8 \text { am, } 9 \text { pm - } 12 \text { am (Monday-Friday) } \\
\text { All day (Saturday-Sunday) }\end{array}$ & $0.06417(\$ / \mathrm{kWh})$ \\
\hline & $\begin{array}{l}\text { January - May, October - December } \\
8 \text { am - } 9 \text { pm (Monday-Friday) }\end{array}$ & $0.08487(\$ / k W h)$ \\
\hline & $\begin{array}{l}\text { June - September } \\
12 \text { am }-8 \text { am, } 11 \text { pm - } 12 \text { am (Monday-Friday) } \\
\text { All day (Saturday-Sunday) }\end{array}$ & $0.05939(\$ / \mathrm{kWh})$ \\
\hline & $\begin{array}{l}\text { June - September } \\
8 \text { am - Noon, } 6 \text { pm - } 11 \text { pm (Monday-Friday) }\end{array}$ & $0.08047(\$ / \mathrm{kWh})$ \\
\hline & $\begin{array}{l}\text { June - September } \\
\text { Noon }-6 \text { pm (Monday-Friday) }\end{array}$ & $0.12343(\$ / \mathrm{kWh})$ \\
\hline
\end{tabular}




\subsubsection{System configuration}

The peak load for the Los Angeles facility was $246 \mathrm{~kW}$. To serve approximately half of this peak load, a PV system of $125 \mathrm{kWdc}$ nameplate capacity was considered. A smaller $50 \mathrm{kWdc}$ installation was also considered. For each system, a parametric set of battery sizes ranging from $0 \mathrm{kWh}$ to $150 \mathrm{kWh}$ was considered.

\subsubsection{Incentives}

Through its Self-Generation Incentive Program, the State of California offers advanced energy storage incentives of $\$ 1.62 / \mathrm{W}$, up to a system size of one MW [2]. One restriction on the incentive is that the project installer cannot receive an incentive greater than $60 \%$ of eligible project costs. The rated capacity of the energy storage system is calculated as the average discharge power output over a two-hour period. For storage projects coupled with generation technologies such as PV, the rated capacity of the storage cannot be larger than the rated capacity of the PV system. State incentives for PV are no longer available within the SCE service area [18], but the federal residential renewable energy tax credit of $30 \%$ is available [19].

\subsection{Knoxville System}

To provide contrast to the heavily incentivized California system, a primary/secondary school near Knoxville, TN was considered.

\subsubsection{Facility}

The school listed as EnerNOC facility 101 is $274,418 \mathrm{ft}^{2}$ and had a peak load of about $1300 \mathrm{~kW}$ in 2012.

\subsubsection{Utility rate structure}

For a commercial facility with a peak load of about $1300 \mathrm{~kW}$, the Knoxville Utilities Board offers the general power rate schedule GSA [20]. Values were again reproduced from the URDB.

\begin{tabular}{l|l|l}
\hline Charge & Time & Cost \\
\hline Fixed charge & All & $140(\$)$ \\
\hline Base demand charge & $\begin{array}{l}\text { January - May, October - December } \\
\text { First 1000 kW / Over } 1000 \mathrm{~kW}\end{array}$ & $11.76 / 13.18(\$ / \mathrm{kW})$ \\
\hline & $\begin{array}{l}\text { June }- \text { September } \\
\text { First } 1000 \mathrm{~kW} / \text { Over } 1000 \mathrm{~kW}\end{array}$ & $12.52 / 13.94(\$ / \mathrm{kW})$ \\
\hline Energy charge & All year & $0.06641(\$ / \mathrm{kWh})$ \\
\hline
\end{tabular}

\subsubsection{System configuration}

The peak load for the Knoxville facility was $1296 \mathrm{~kW}$. One set of simulations considered a PV installation of $270 \mathrm{~kW}$, while a second set considered a $650 \mathrm{~kW}$ system. For each simulation, a parametric set of battery sizes ranging from $0 \mathrm{kWh}$ to $450 \mathrm{kWh}$ was considered. 


\subsubsection{Incentives}

The state of Tennessee offers an incentive that rebates $100 \%$ of sales and use tax on photovoltaics in addition to other renewable technologies [18]. The federal energy investment tax credit of $30 \%$ was also applied.

\subsection{System Costs and Financial Parameters}

For the analysis there are many financial parameters to be considered which could impact the value of installing a battery system. Battery costs are captured on a $\$ / \mathrm{kWh}$ basis as reported by vendors. Installation labor, margin, operation and maintenance, and other costs are captured as a function of the size of the installed PV system using the defaults in SAM. The battery bank is assumed to be DC connected such that battery power output is inverted to AC using the same inverter as the PV system.

Table 7: System Costs

\begin{tabular}{l|l}
\hline Variable & Value \\
\hline Module cost & $0.71 \$ / \mathrm{Wdc}$ \\
\hline Inverter cost & $0.21 \$ / \mathrm{Wdc}$ \\
\hline Battery cost & $\$ 300 / \mathrm{kWh}$ Lithium lon \\
& $\$ 255 / \mathrm{kWh}$ Lead Acid \\
\hline Balance of system equipment & $0.57 \$ / \mathrm{Wdc}$ \\
\hline Installation labor & $0.15 \$ / \mathrm{Wdc}$ \\
\hline Installer margin and overhead & $0.75 \$ / \mathrm{Wdc}$ \\
\hline Permitting & $0.06 \$ / \mathrm{Wdc}$ \\
\hline Operation and Maintenance & $20 \$ / \mathrm{kW}-\mathrm{yr}$ \\
\hline
\end{tabular}

To compute the net present value of the system for each scenario considered, the analysis is conducted using the values in Table 8 . 
Table 8: Financial parameters

\begin{tabular}{l|l}
\hline Variable & Value \\
\hline Analysis period & 25 years \\
\hline Debt percent & $100 \%$ \\
\hline Loan term & 25 years \\
\hline Loan rate & $7.5 \%$ per year \\
\hline Inflation rate & $2.5 \%$ \\
\hline Real discount rate & $5.5 \%$ \\
\hline $\begin{array}{l}\text { Nominal discount } \\
\text { rate }\end{array}$ & $8.14 \%$ \\
\hline Depreciation & $5-y$ MACRS \\
\hline Federal income tax & $28 \%$ per year \\
\hline State income tax & $7 \%$ per year \\
\hline Sales tax & $\begin{array}{l}5 \% \text { of installed cost } \\
(\text { None in Knoxville after incentive })\end{array}$ \\
\hline
\end{tabular}

\subsection{Financial metrics}

To evaluate the economic performance of a system, two financial metrics were considered for each simulation. The metrics described are implemented according to [21].

\subsubsection{Net Present Value}

The net present value (NPV) is a way to examine costs and revenues while accounting for the time value of money. If the NPV of a system is positive, then the investment is predicted to provide a return on investment greater than the initial and ongoing cash expenditures associated with ownership of the system. A negative NPV indicates the returns are worth less than the cash outflows and the investment does not show a financial benefit, although unquantified benefits may be present. NPV is a valuable metric to consider for PV coupled with storage systems, since variable battery bank replacements (cash outflows) can be captured and discounted depending on the year the replacement occurs.

\subsubsection{Payback Period}

The payback period (PBP) is the time in years it takes for project savings in years two and later of the project to equal or exceed the initial cost. This metric is included because of its ability to quickly communicate tangible value of a project. A system which yields a very short payback period is typically a profitable one because subsequent years of the project result in pure revenue for the system owner. A system which cannot be paid back over the lifetime of the system is a poor investment because money is still owed when the system is retired and no longer able to generate revenue.

One complication of using the payback period to evaluate PV coupled with storage is that battery bank replacements vary in timing and may become necessary during the system lifetime. A project which has paid off its debt may eventually have to incur more debt to replace a battery 
bank. The payback period is reported as the first time where the project savings exceeds the debt, but care must be taken to also consider additional cash expenditures in later years. 


\section{Results and Discussion}

\subsection{Varying Battery Bank Size}

To examine the financial implications of differently sized battery installations for demand charge reduction, the automated peak shaving controller was used with a fixed size PV installation and varying sizes of battery bank. Modifying the battery bank size also changed the battery bank voltage and incentive level. Varying the lithium-ion battery bank size for two PV system sizes resulted in changing NPVs and PBPs as shown in Figure 3 for California and in Figure 4 for Tennessee.

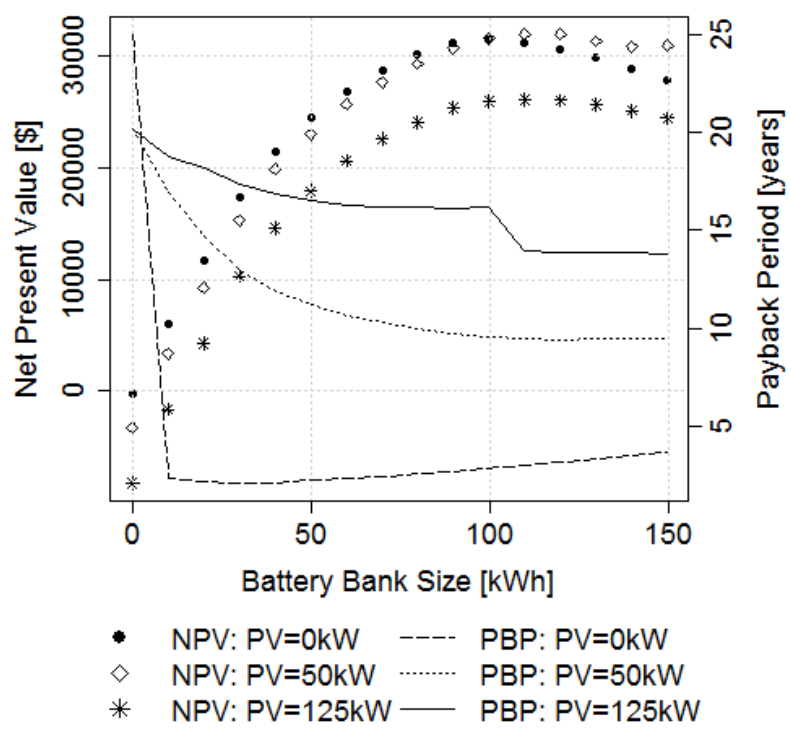

Figure 3: Los Angeles, lithium ion system with automatic dispatch

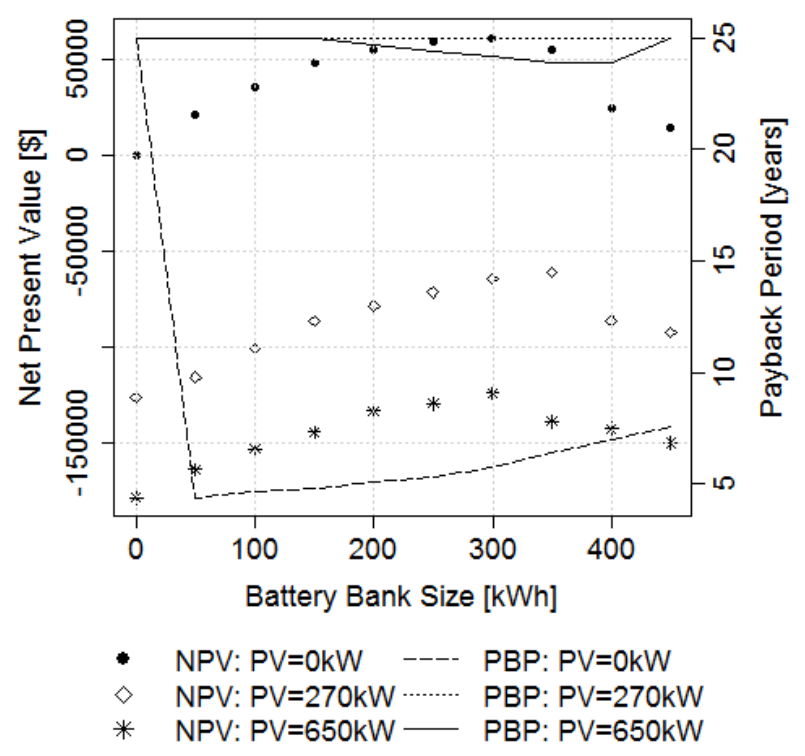

Figure 4: Knoxville, lithium ion system with automatic dispatch

For Los Angeles, it is apparent that increasing the battery bank size up to about $100 \mathrm{kWh}$ improves the net present value and payback period for this particular system using perfect dayahead forecasting of weather and electric load. As the battery size increases above $100 \mathrm{kWh}$, the additional battery cost is greater than the reduction of demand charges. Reducing the size of the PV system, or eliminating it altogether, improves the net present value and payback periods, because most load occurs early in the morning and late in the evening when PV production is low. The payback period for the $125 \mathrm{~kW}$ PV system declines from about 17 years to 14 years when the battery bank is increased from $100 \mathrm{kWh}$ to $110 \mathrm{kWh}$. This is because of increased demand charge reduction, which improves the project savings and yields a cumulative savings greater than project debt before a battery bank replacement occurs. For smaller battery systems, the battery bank is replaced before the savings exceeds the project debt, prolonging the payback period.

For Knoxville, no battery size adds financial value for the system studied when accompanied with PV panels. When a battery is installed without any PV there is a positive net present value for all battery sizes considered. The simulation does not compute payback periods greater than the analysis period such that 25 years is the maximum payback period computed, and could indicate an even longer payback. 


\subsection{Varying Battery Chemistry}

Switching to the lead-acid battery bank and examining alternately sized battery banks revealed major differences in financial metrics compared to the lithium-ion results above. For the leadacid battery system, the daily cycle process results in battery bank replacements every six or seven years. Over the course of 25 years, these more frequent replacements result in large capital costs. Consequently, installation of this system for DCR under the current assumptions does not add financial value for either facility for the two PV system sizes considered. Figure 5 shows that there is not a positive net-present value for any configuration considered. The payback period increases as the battery bank size increases and eventually reaches the system lifetime. Figure 6 illustrates the cash flows of a lead-acid battery scenario.
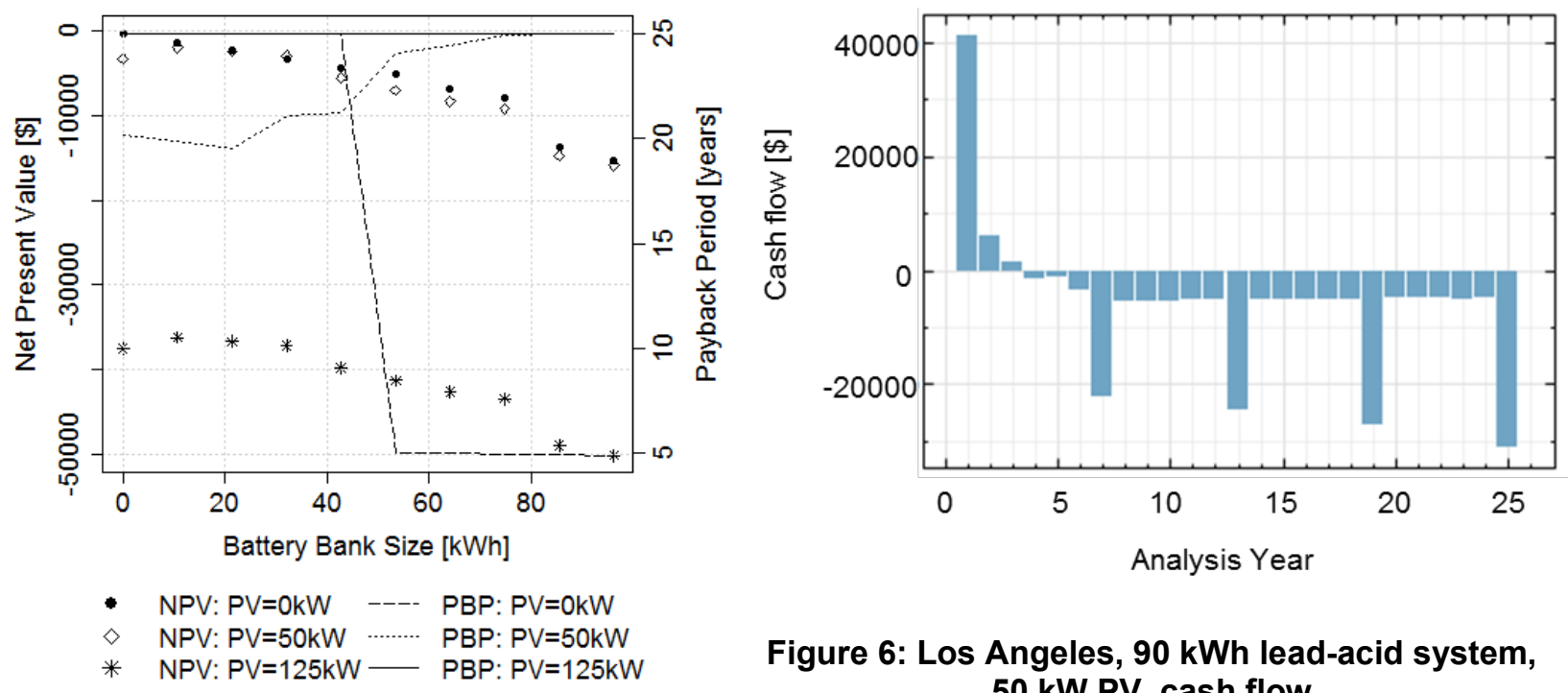

Figure 6: Los Angeles, $90 \mathrm{kWh}$ lead-acid system, $50 \mathrm{~kW}$ PV, cash flow

\section{Figure 5: Los Angeles, lead acid system with} automatic dispatch

In the first year, a large cash influx occurs as cash incentives and tax savings are accrued. Fiveyear MACRS depreciation contributes to net positive cash flows over the first three years. Eventually depreciation is not enough to offset the debt payments. In year seven, the first battery replacement occurs resulting in a large negative cash flow. Three additional battery bank replacements occur over the rest of the analysis period, offsetting the financial benefit of installing storage to reduce demand charges.

\subsection{Varying Storage Dispatch}

Previous results have considered using a perfect day-ahead forecasting to automate battery dispatch for peak shaving. The present version of SAM offers a manual dispatch controller that allows a user to specify when to charge and discharge the battery, and how much to discharge. The scheduling is possible on an hourly basis for each month. The manual dispatch controller was used to compare against the automatic strategy. Figure 7 and Figure 6 show that the manual controller is insufficient to generate a positive net-present value for any battery size regardless of whether a PV system is installed in Los Angeles or Knoxville at the system configurations previously described. The payback period shown cannot exceed the analysis period of the 
system, but actual payback period would keep increasing beyond 25 years as the battery bank energy increases.

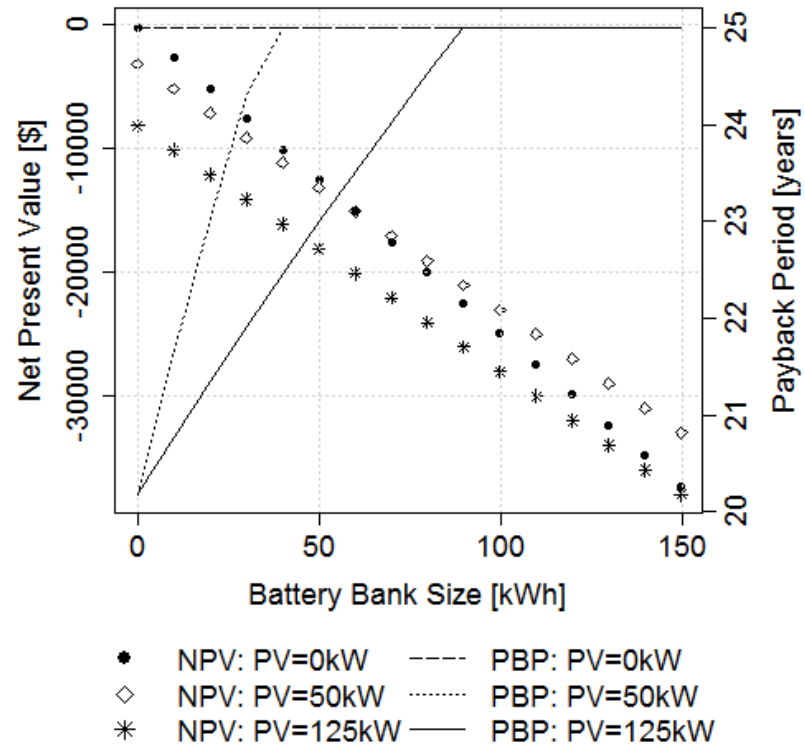

Figure 7: Los Angeles, lithium ion system with manual dispatch

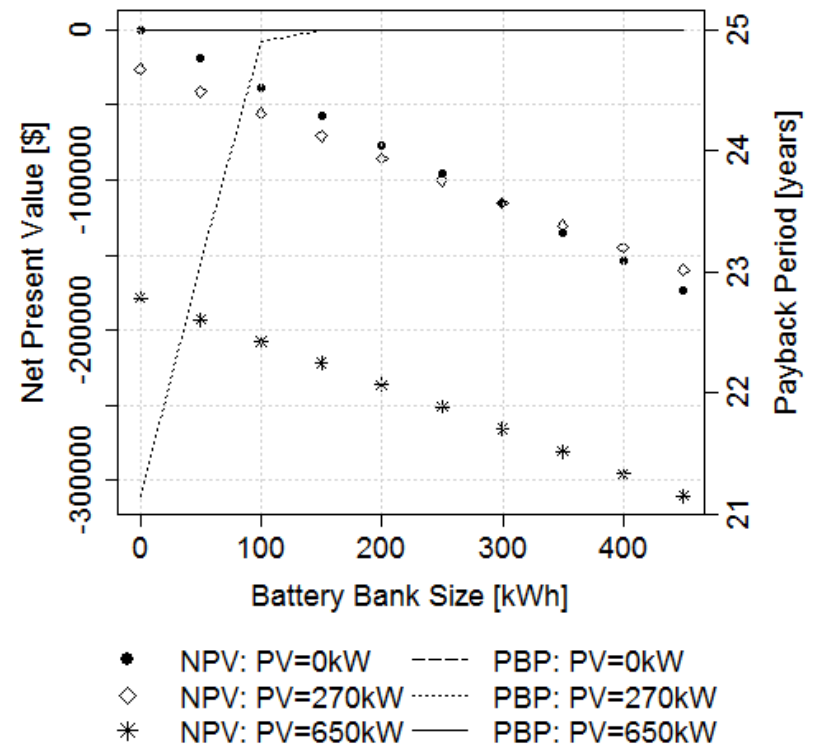

Figure 8: Knoxville, lithium ion system with manual dispatch

The manual dispatch controller is insufficient for peak shaving applications because of the variable nature of load demand. Though the schedule was tailored to dispatch the battery in typical times of high demand, the controller naively follows its preset schedule even when other spikes occur. Differences in monthly demand charges between these two scenarios reflect spikes that could have been predicted by a day-ahead forecast but are not included in the typical demand profile used to set the manual dispatch. Because demand charges are based on the highest peak over the month, any unexpected spike which cannot be offset by the battery negates any savings that may be accrued. Similar differences between perfect day-ahead forecasting and manual dispatch control are obtained regardless of the location or battery chemistry.

\subsection{Best Case Summary}

For the two locations studied, the following configurations yielded the best net-present value.

Table 9: Best case summary

\begin{tabular}{l|l|l}
\hline & Los Angeles & Knoxville \\
\hline Net Present Value & $\$ 31,874$ & $\$ 60,731$ \\
\hline Battery Bank Size & $110 \mathrm{kWh} / 55 \mathrm{~kW}$ & $300 \mathrm{kWh} / 150 \mathrm{~kW}$ \\
\hline PV Array Size & $50 \mathrm{~kW}$ & $0 \mathrm{~kW}$ \\
\hline Dispatch Strategy & Automatic & Automatic \\
\hline Battery Chemistry & Lithium lon & Lithium lon \\
\hline
\end{tabular}




\section{Conclusions}

The financial impact of adding PV+Storage to two commercial facilities in different locations was examined using SAM. Multiple sizes of battery banks and PV systems were considered. Lithium ion and lead acid batteries were used to evaluate the tradeoffs between cost and cycle life. With a perfect 24 hour forecast for weather and load data, an automated dispatch controller was used to reduce demand charges and compared against a simpler manual control strategy.

Installing PV in Knoxville yielded a negative NPV for the sizes considered. Adding a lithium-ion battery system with automatic peak shaving control mildly improved the investment but did not offset the large negative NPV of the system. With no PV system, installing a lithium-ion system in Knoxville yielded a positive NPV for all battery sizes considered. Installation of a lithium-ion battery system in Los Angeles while using the automatic peak-shaving strategy yielded a positive NPV for most system sizes, illustrating that battery energy storage may prove valuable with specific utility rates, ideal dispatch control, long cycle life and favorable battery costs. The leadacid batteries considered needed to be replaced more frequently, resulting in large recurring capital costs that led to negative NPVs for both locations and dispatch strategies. Using the manual dispatch strategy proved insufficient for consistently shaving load peaks regardless of location or battery type.

It is clear that many details should be considered when evaluating the economic potential of behind-the-meter storage for demand-charge reduction. In addition to considering the weather and load profiles of the site, it is necessary to evaluate the utility rate structure, and determine whether the addition of battery storage can be leveraged to reduce costs enough to justify the upfront capital expenditure and replacement costs. The greatest financial benefit will be derived at certain sizes of PV and battery couplings, requiring optimization or parametric analysis. Further complications result when considering how to dispatch the battery to maximize its benefit, especially because load and weather forecasts are uncertain, and battery lifetime depends on cycling behavior. SAM provides a means to begin evaluating these complex problems. 


\section{References}

[1] California Public Utilities Commission, "Assembly Bill 2514 Decision," 3 September 2013. [Online]. Available:

http://docs.cpuc.ca.gov/PublishedDocs/Published/G000/M078/K912/78912194.PDF.

[2] California Public Utilities Commission, "2014 Self-Generation Incentive Program Handbook," CPUC, 2014.

[3] ConEdison, "Demand Management Initiatives," 2015. [Online]. Available:

http://www.coned.com/energyefficiency/demand_management_incentives.asp.

[4] D. Shimogawa, "Hawaii Electric to use energy storage project developed by California startup," Pacific Business News, 11 September 2014. [Online]. Available: http://www.bizjournals.com/pacific/blog/morning_call/2014/09/hawaiian-electric-to-useenergy-storage-project.html.

[5] J. Neubauer and M. Simpson, "Deployment of Behind-The-Meter Storage for Demand Charge Reduction," National Renewable Energy Laboratory, Golden, 2015.

[6] Southern California Edison, "NEM FAQ," 2015. [Online]. Available: https://www.sce.com/wps/portal/home/residential/generating-your-own-power/net-energy-

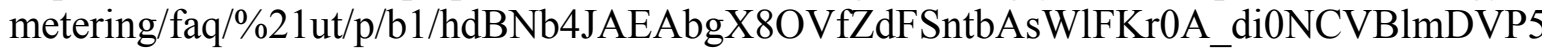

10YPtV9zm8nzTjJDJCmJ7KpDo6qh0V3VHnvpLakf86koIPwo8SCCh_vcDVLqPrkGLAz AL8XxX_6FyAsSsMgQ5Bmfc9yFziWIb2.

[7] P. Gilman, "SAM Photovoltaic Model," National Renewable Energy Laboratory, Golden, 2015.

[8] N. DiOrio, A. Dobos, S. Janzou, A. Nelson and B. Lundstrom, "Technoeconomic Modeling of Battery Energy Storage in SAM," National Renewable Energy Laboratory, Golden, 2015.

[9] EnerNOC, "2012 Commercial Energy Consumption Data," 2013. [Online]. Available: https::/open-enernoc-data.s3amazonaws.com/anon/index.html. [Accessed 24 August 2015].

[10] SunPower, "SunPower," [Online]. Available: http:://us.sunpower.com. [Accessed 21 August 2015].

[11] SMA America, "SMA America," 2015. [Online]. Available: http://www.sma-america.com/.

[12] D. Linden and T. Reddy, Linden's Handbook of Batteries - 4th Edition, New York : McGraw Hill, 2011.

[13] Tesla Motors, "Powerwall," 2015. [Online]. Available: 
http://www.teslamotors.com/powerwall. [Accessed 14 August 2015].

[14] Outback Power, "Energy Cell RE," [Online]. Available:

http://www.outbackpower.com/outback-products/energy-storage/item/energycellre?category_id=442. [Accessed 17 August 2015].

[15] altE Store, "Outback Power EnergyCell 200RE 12V 178 AH AGM Battery," [Online]. Available: http://www.altestore.com/store/Deep-Cycle-Batteries/Batteries-SealedAgm/Outback-Power-EnergyCell-200RE-12V-178AH-AGM-Battery/p9857/. [Accessed 17 August 2015].

[16] Southern California Edison, "General Service Demand GS2," 30 Jan 2015. [Online]. Available: https://www.sce.com/NR/sc3/tm2/pdf/ce30-12.pdf. [Accessed 14 Aug 2015].

[17] OpenEI, "Utility Rate Database," [Online]. Available: http://en.openei.org/apps/USURDB/rate/view/539fc260ec4f024c27d8b167\#2_Demand. [Accessed 14 August 2015].

[18] DSIRE, "California Solar Initiatives - PV Incentives," 18 June 2015. [Online]. Available: http://programs.dsireusa.org/system/program/detail/2362. [Accessed 17 August 2015].

[19] U.S. Department of Energy, "Residential Renewable Energy Tax Credit," [Online]. Available: http://energy.gov/savings/residential-renewable-energy-tax-credit. [Accessed 17 August 2015].

[20] Knoxville Utilities Board, "Electric Rate Schedules," [Online]. Available: http://tinyurl.com/nte9t36. [Accessed 24 August 2015].

[21] W. Short, D. J. Packey and T. Holt, "A Manual for the Economic Evaluation of Energy Efficiency and Renewable Energy Technologies," National Renewable Energy Laboratory, Golden, 1995. 